Hydrology and Earth System Sciences, 8(2), 205-219 (2004) C EGU

\title{
Nitrogen Risk Assessment Model for Scotland: II. Hydrological transport and model testing
}

\author{
S.M. Dunn ${ }^{1}$, A. Lilly ${ }^{1}$, J. DeGroote ${ }^{1}$ and A.J.A. Vinten ${ }^{2}$ \\ ${ }^{1}$ Macaulay Institute, Craigiebuckler, Aberdeen, AB15 8QH, Scotland \\ ${ }^{2}$ Scottish Agricultural College, Bush Estate, Penicuik, Midlothian, EH26 OPH, Scotland \\ E-mail of corresponding author: s.dunn@macaulay.ac.uk
}

\begin{abstract}
The amount and concentration of $\mathrm{N}$ in catchment runoff is strongly controlled by a number of hydrological influences, such as leaching rates and the rate of transport of $\mathrm{N}$ from the land to surface water bodies. This paper describes how the principal hydrological controls at a catchment scale have been represented within the Nitrogen Risk Assessment Model for Scotland (NIRAMS); it demonstrates their influence through application of the model to eight Scottish catchments, contrasting in terms of their land use, climate and topography. Calculation of $\mathrm{N}$ leaching rates, described in the preceding paper (Dunn et al., 2004), is based on soil water content determined by application of a weekly water balance model. This model uses national scale datasets and has been developed and applied to the whole of Scotland using five years of historical meteorological data. A catchment scale transport model, constructed from a $50 \mathrm{~m}$ digital elevation model, routes flows of $\mathrm{N}$ through the sub-surface and groundwater to the stream system. The results of the simulations carried out for eight different catchments demonstrate that the NIRAMS model is capable of predicting time-series of weekly stream flows and N concentrations, to an acceptable degree of accuracy. The model provides an appropriate framework for risk assessment applications requiring predictions in ungauged catchments and at a national scale. Analysis of the model behaviour shows that streamwater $\mathrm{N}$ concentrations are controlled both by the rate of supply of $\mathrm{N}$ from leaching as well as the rate of transport of $\mathrm{N}$ from the land to the water.
\end{abstract}

Keywords: nitrogen, diffuse pollution, hydrology, model, transport, catchment

\section{Introduction}

Dunn et al. (2004) described the development of the nitrogen leaching component of the NItrogen Risk Assessment Model for Scotland (NIRAMS). To predict the integrated effect of the $\mathrm{N}$ leaching on surface waters at a catchment scale, the processes describing the hydrological transport and mixing of waters must also be modelled. Different catchments can then be ranked against each other in terms of their relative risk of diffuse pollution by $\mathrm{N}$.

Several different hypotheses have been proposed to explain the patterns of temporal variability in $\mathrm{N}$ concentrations observed in stream waters. Without exception the hypotheses involve some form of hydrological influence. One mechanism that has been proposed is that of $\mathrm{N}$ flushing (Creed et al., 1996). During periods of high saturation deficits, $\mathrm{N}$ accumulates in the upper layers of the soil; then, as the saturation deficit decreases and the water table rises,
$\mathrm{N}$ is flushed from the upper layers of the soil to increase streamwater $\mathrm{N}$ concentration on the rising limb of the hydrograph.

The $\mathrm{N}$ flushing concept assumes that streamwater concentrations reflect variations in $\mathrm{N}$ leaching rates, and hence assumes short residence times within the catchment. A recent study by Ruiz et al. (2002a) demonstrated that the nitrate concentration in streamwater was not linked directly to the nitrate concentration in drainage water. Rather, during the transfer of nitrate from the bottom of the soil to the stream, a buffering effect was observed that damped out variations in nitrate concentration at the catchment scale. Similarly, in a study of 17 Danish catchments, Andersen et al. (2001) found no relationship between net $\mathrm{N}$ catchment export and root zone $\mathrm{N}$ leaching and ascribed the finding to a high retention of $\mathrm{N}$ during subsurface transport to the stream. 
An alternative mechanism to describe temporal variability has, therefore, been proposed, based on the hypothesis that streamwater nitrate concentrations are transport- rather than supply-limited. Ruiz et al. (2002b) describes a methodology for explaining the temporal variability in streamwater concentrations by the mixing of water derived from several sources with different characteristic concentrations. These waters mix in varying proportions, leading to a complex $\mathrm{N}$ response signal. This general hypothesis may be explained by a number of potential influencing factors, including transportation times, mixing of old and new water, and topographic influences, which alter the pathways of waters. A simple example of the mixing concept has been widely applied to other chemical determinands through End Member Mixing Analysis (EMMA) (e.g. Christopherson et al., 1990; Soulsby et al., 1998; Wade et al., 1999). EMMA has not generally been considered appropriate for $\mathrm{N}$ modelling, because it assumes constant solute concentrations that characterise the different sources of water within a catchment. However, some success has been achieved in using nitrate as an end-member over short time periods, for flow separation of storm events (Petry et al., 2002; Soulsby et al., 2003), by identifying differences in nitrate concentration between waters sourced from overland flow, subsurface flow from agricultural field drains and groundwater.

One of the commonly observed characteristics of streamwater $\mathrm{N}$ signals is a dilution effect at the peak of the hydrograph (Cooper and Roberts, 1996; Soulsby et al., 2003). This can be explained by the occurrence of overland flow where water is transported very rapidly to a surface stream. The overland flow water has only limited contact with the soil matrix, resulting in relatively low removal of $\mathrm{N}$.

At drier times, when overland flow is not taking place, leached $\mathrm{N}$ is likely to be transported by a mixture of shallow sub-surface flows through the soil matrix and into field drains, and deeper groundwater flows. The relative importance of these two flow paths will be highly dependent on the nature of the soils and topography as well as on the hydrological conditions at a particular time (Molenat et al., 2002). Topography is important in a number of ways. At its simplest, the definition of up-slope drainage area determines the source areas for leached $\mathrm{N}$ to contribute to the stream network at a particular point. At a more complex level, the slopes of the terrain influence soil moisture and rates of transportation, whilst the amount of runoff may vary across the catchment with spatial variability in rainfall inputs and evapotranspiration losses. Because there is often a correlation between land use and within-catchment 'location', the ability to account for this heterogeneity in catchment properties can be advantageous for modelling.
In a regression analysis study of 414 catchments in the United States, both soil permeability and stream density were significant predictors of $\mathrm{N}$ transport in addition to the more obvious relationships with land use (Smith et al., 1997).

The incorporation of spatial processes has commonly been neglected in simple catchment-scale models of nitrogen transport, despite its apparent importance. The MAGPIE model (Lord and Anthony, 2000) uses spatially varying hydrological inputs, at a resolution of $1 \mathrm{~km}^{2}$ but no other physical properties of the catchment were used to estimate the rate of runoff. Instead, a calibration is carried out at the catchment scale to account for "some mixing and delay... to allow for the time taken for water to move through subsoils, ditches and hillslopes". Within the INCA model, transport rates are varied only as a function of the mean sub-catchment baseflow index (Whitehead et al., 1998). This effectively integrates some of the variability at a subcatchment scale but gives no information about residence times within the sub-surface or groundwater. Leon et al. (2001) defined representative grid cells on the basis of land cover classes, but assumed that the location of the particular land cover classes was not significant.

From the foregoing discussion, it is apparent that hydrology exerts an important influence on the variability in stream $\mathrm{N}$ concentrations and that adequate representation of these processes within a model will be central to the success of its predictive capability. This paper describes the methodology that has been developed for the NIRAMS model to represent the influences of hydrological transport on streamwater $\mathrm{N}$ concentrations. The paper concludes with a test application of the full NIRAMS model to eight catchments in Scotland, as a demonstration of its capability.

\section{Hydrological controls in NIRAMS}

In the development of the hydrological transport component for NIRAMS, an attempt has been made to incorporate the main hydrological controlling features discussed above as being of significance in determining concentrations of nitrates in stream water. In modelling terms, three distinct types of hydrological control have been identified.

(i) The amount of $\mathrm{N}$ leached at any given time is dependent on the soil water content (following eg. Burns, 1980; Shaffer et al., 1994; Anthony et al.; 1996, Lin et al., 2001).

(ii) The proportion of $\mathrm{N}$ lost by different flow paths (by overland flow, through the soil matrix or by groundwater) varies according to the wetness of the soil (eg. Robson et al., 1992; Beaujouan et al., 2001).

(iii) Transportation times and mixing with other waters 
depend on the location in the catchment as well as the flow paths (Molenat et al., 2002).

Because of the required national scale of application of NIRAMS, the methodology had to be kept as simple as possible, but at the same time incorporation of many controlling factors was desirable, so that the model could be extrapolated reliably to areas with no available model calibration data. In particular, the inclusion of a spatial analysis should reduce the need for catchment specific calibration of parameters, by including many of the controlling influences. NIRAMS includes two distinct hydrological components. The hydrological fluxes at each point on the land surface are calculated using a water balance model that is applied to the whole of Scotland. The component to model hydrological transport to surface waters and spatial integration is then applied to specific catchment areas. The theories of these two model components are described separately.

\section{Water balance model structure}

\section{REQUIREMENTS}

The NIRAMS water balance model has two principal functions; firstly, it calculates the amount of water available in the soil for $\mathrm{N}$ leaching at any time and, secondly, it apportions the leachate between different hydrological flowpaths for transport to the stream network. The model must be capable of being applied spatially at a resolution that captures the major variability in hydrology and soil properties. Temporally, the model must identify whatever runoff mechanisms are operational at different times. Monthly water balances were deemed to be inadequate to distinguish between hydrological processes, whilst daily balances would require excessive computation for spatial application at a national scale. A temporal resolution of one week was, therefore, selected for the model time-step. Spatially, a grid resolution of $1 \mathrm{~km}^{2}$ was selected as a level appropriate for capturing, for subsequent integration and interrogation at the catchment scale, the principal variations in meteorological measurements and soil hydrological properties

\section{MODEL STRUCTURE}

Figure 1 is a schematic of the water balance model, which has been developed from an approach for a national-scale assessment of the impacts of potato irrigation in Scotland (Crabtree et al., 2002; Dunn et al., 2003).. For each $1 \mathrm{~km}^{2}$ grid cell, a weekly balance is calculated of the inputs and
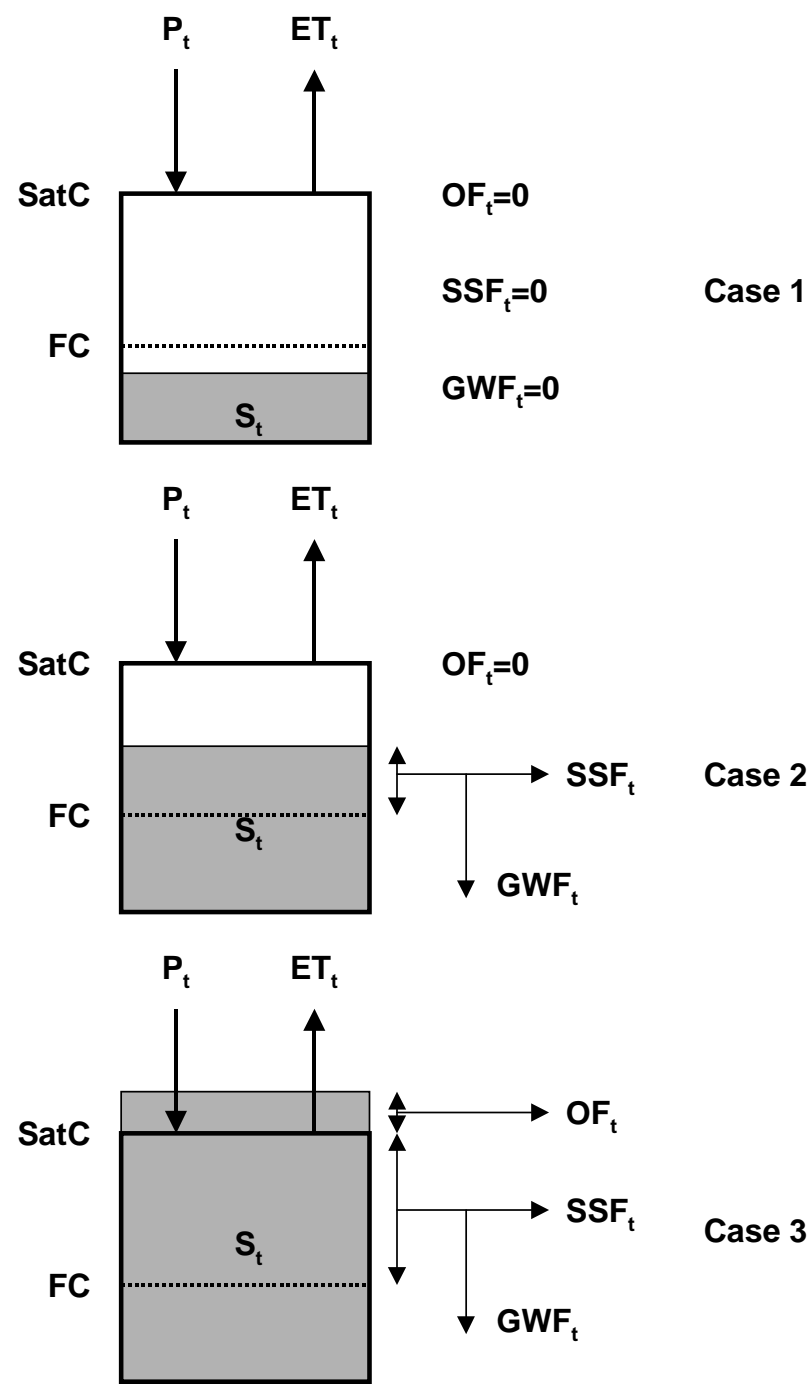

Fig. 1. Schematic of water balance model showing flows from cell under different soil moisture conditions

outputs to the soil system:

$$
S_{t}=S_{t-1}+P_{t}-E T_{t}-F_{t}
$$

where $S_{t}$ is the soil moisture storage (m) for week $t, S_{t-1}$ is the soil moisture storage from the previous week, $\mathrm{P}_{\mathrm{t}}$ is the precipitation input $(\mathrm{m})$ for week $t, E T_{t}$ is the evapotranspiration (m) for week $t, F_{t}$ is the total flow out of the grid cell (m) for week $t$.

Inputs to the model are weekly maps of precipitation and evapotranspiration, as well as data on soil hydrological properties, such as field capacity and saturation water content. It is assumed that net precipitation enters the soil, where it is added to the existing soil storage. Flows out of each grid cell are partitioned into overland flow $(O F)$, sub- 
surface flow ( $S S F)$ and groundwater flow $(G W F)$, depending on the soil moisture conditions at each time-step, as shown in Fig.1. Three different states are considered:

(i) soil moisture storage $<$ field capacity (Case 1 in Fig.1);

(ii) field capacity $<$ soil moisture storage $<$ saturation capacity (Case 2 in Fig.1);

(iii) soil moisture storage $>$ saturation capacity (Case 3 in Fig.1).

In situation (i) there is no drainage from the soil column. In situation (ii) there is both drainage to groundwater and subsurface flow loss. In situation (iii) overland flow occurs, generated by the water in excess of saturation capacity, as well as drainage to groundwater and loss to sub-surface flow. The relative amounts of sub-surface flow and groundwater depend on the soil moisture and, also, vary between different soils according to two different calibration parameters. Essentially, the loss to groundwater, $G W F$, is defined by:

$$
G W F_{t}=P O R E \times\left(S_{t}-F C\right) / K V
$$

where $P O R E$ is the soil porosity (determined from saturated water content), $F C$ is the soil field capacity (m) and $K V$ is the vertical drainage calibration parameter.

The loss to sub-surface flow, $S S F$, is defined by:

$$
S S F_{t}=\left(S_{t}-F C\right) /(P O R E \times K L)
$$

where $K L$ is the lateral flow calibration parameter

\section{WATER BALANCE MODEL DATA}

\section{Precipitation}

Measurements of precipitation from daily raingauges covering the whole of Scotland were sourced from the NERC BADC (British Atmospheric Data Centre) archive for the 10-year period from 1989-1998. The data were accumulated into weekly totals and maps of weekly precipitation, at a grid resolution of $1 \mathrm{~km}^{2}$, were derived by spatial interpolation. Gauges with periods of missing data were excluded from the interpolation for the duration of their missing values. The raw data of weekly total precipitation were also screened visually to identify any obvious error, such as a zero value when all surrounding gauges had recorded precipitation; in such situations, the gauges were excluded from the interpolation for that period.

A Universal Kriging method was applied to logarithms of the precipitation data to model the data spatially. Universal Kriging is a good technique for modelling precipitation (Goovaerts, 2000; Yuan and Duchon, 2001) because it incorporates an external drift component that takes account of the influence of factors such as topography and geography in determining rainfall amounts. For the present application, a linear function was used to model the drift. Interpolation of the log data gave a more stable output than the raw precipitation data, because of the high degree of skewness in the distribution. Different Kriging model parameters were evaluated through examination of the output semi-variance and a model, based on interpolation of up to 10 raingauges within a $30 \mathrm{~km}$ radius, gave the least semi-variance when averaged across the whole country.

The feasibility of directly incorporating altitude as a covariant within the kriging procedure was investigated but it was found to give little benefit due to the scarcity of data from higher altitudes. The degree to which altitude influences precipitation is not uniform across Scotland and, therefore, a simple nationally applicable methodology could not be identified. Given that the areas where precipitation enhancement is most significant (in the mountains) do not correspond to areas at high risk from $\mathrm{N}$ pollution, it was felt that the model would not be affected unduly by this limitation in terms of its prediction of risk.

\section{Evapotranspiration}

Data from meteorological stations across the whole of Scotland were also sourced from the BADC archive to calculate evapotranspiration rates for input to the water balance model. Depending on the year, the number of stations for which data were available varied from 27 to 43 . Although there is high spatial heterogeneity in variables such as radiation and windspeed, their influences on errors in the water balance model are small compared with potential errors in precipitation measurements. Not only is the variability in evapotranspiration lower than that in precipitation but evapotranspiration is a smaller component of the water balance. A simple proximity analysis was used to assign evapotranspiration values spatially.

Weekly evapotranspiration rates were calculated using the Penman-Monteith method. Daily measurements of wet and dry-bulb temperatures, number of sun hours, and wind speed were used to estimate vapour pressure deficit, net radiation, aerodynamic resistance and slope of the vapour pressure / temperature curve, using standard techniques (Wiesner, 1970; Allen et al., 1998). Values for the evapotranspiration parameters were selected that were consistent with a land cover of grassland (Dunn and Mackay, 1995), to give appropriate mean figures when averaged across most catchments and to simplify the representation. Missing data were infilled by linear regressions of calculated evapotranspiration between neighbouring stations.

To limit evapotranspiration during very dry periods, the 
potential evapotranspiration rates, ET, were modified within the water balance model using calculated values of the soil storage in relation to field capacity. The actual evapotranspiration, $A E T$, is calculated by:

$$
\begin{array}{ll}
A E T_{t}=\frac{E T_{t} \times S_{t}}{0.7 \times F C} \text { when } S_{t}<0.7 \times F C \\
A E T_{t}=E T_{t} \quad \text { when } S_{t} \geq 0.7 \times F C
\end{array}
$$

\section{Soil hydrological data}

The water balance model required information on water content at saturation and at field capacity. Notwithstanding a database of approximately 550 measured soil moisture retention curves describing the relationship between applied pressure and moisture content $(\theta(\mathrm{h}))$, it does not encompass all soil types commonly found in Scotland. To predict the moisture contents of those soils without data, a method was derived based on the pedotransfer functions published in the Agricultural Land Classification (ALC) for England and Wales (MAFF, 1988) and including the data from the 550 measured $\theta(\mathrm{h})$ curves. These ALC pedotransfer functions were used to derive soil available water capacities for the range of soil textures commonly found in Scotland and modified to estimate the water content at field capacity and water content at saturation.

Firstly, the soil texture class for each horizon of each soil that occurs on the 1:250 000 scale national soil spatial dataset was determined. Each horizon was assigned an available water capacity value as shown in MAFF (1988) based on texture and on an assessment of soil structure. Available water capacity is defined as water held in the soil between approximately $-50 \mathrm{~cm}$ pressure head (field capacity) and approximately $-15300 \mathrm{~cm}$ (permanent wilting point). The moisture content at field capacity includes the available water capacity plus the water retained in the soil at pressure heads greater than $-15300 \mathrm{~cm}$. To estimate the saturated water content, the volume of soil pores that drain under gravity (pressure heads between 0 and $-50 \mathrm{~cm}$ ) had to be determined and added to the moisture retained at field capacity.

The Scottish Soil Hydrological Database indicated the moisture held within the soil at a pressure head greater than $-15300 \mathrm{~cm}$. The available data were grouped according to soil texture and the mean moisture content was determined for the five topsoil and nine subsoil texture classes represented. The topsoil means varied from 17.6-23.5\% while the subsoil means ranged from 6-29\%. The narrow range of mean values in the topsoil data meant that little distinction could be made within this group. An overall mean of $20 \%$ moisture content was, therefore, chosen to represent the moisture retained in the topsoils at pressure heads greater than $-15300 \mathrm{~cm}$. Visual inspection of the mean values for the nine subsoil groups showed four distinct groups (Fig. 2a) that could be related to contiguous classes in the soil texture diagram (Fig. 2b). The mean moisture content of each of these four groups was determined (Table 1) and applied to contiguous soil texture classes as shown in Fig. 2b. As there were insufficient data on organic soil layers, an average value of $20 \%$ was also applied to these surface horizons.

Table 1. Mean moisture contents at permanent wilting point for the four broad texture classes in Scottish subsoils (those in italics are not represented in the Scottish Soil Hydrological Database).

Soil texture class

Mean value

(percentage moisture content)

Silty clay $(z c)$

28

Silty clay loam (zcl)

Clay (c) ; Sandy clay

Clay loam (cl)

Sandy silt loam (szl); Silt loam

Sandy clay loam (scl)

Sandy loam (sl)

Loamy sand (ls)

Sand (s)

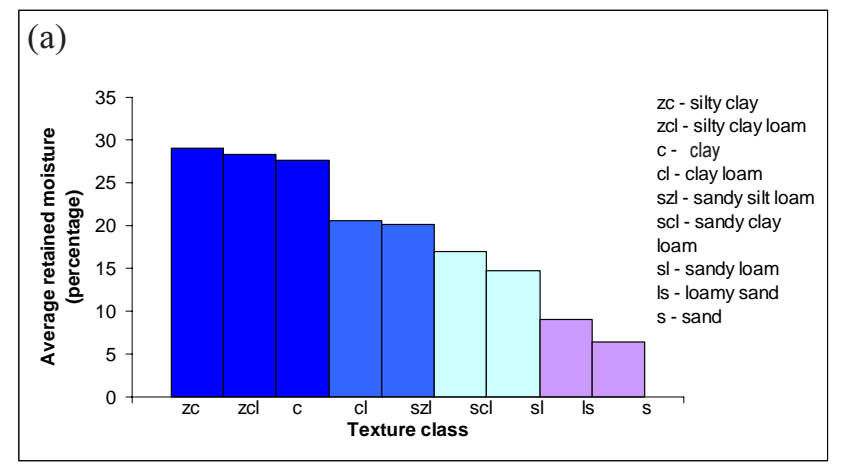

(b)

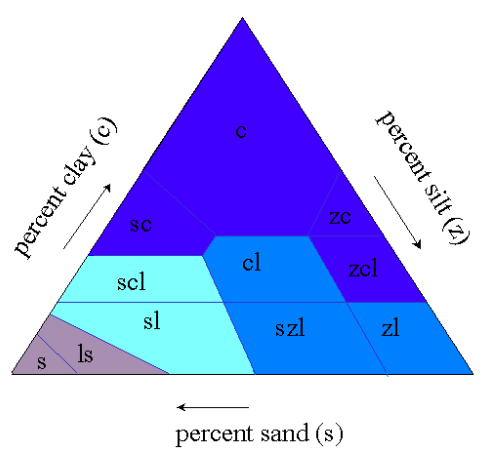

Fig. 2. Mean subsoil moisture contents (at $-15300 \mathrm{~cm}$ pressure head) and soil textural triangle 
These mean values were then added to the respective available water capacity values taken from MAFF (1988). Because stones and gravel in soils would retain only about $1 \%$ moisture (MAFF, 1988), the moisture retained by stony and gravelly soils was reduced in proportion to the estimated stone content.

$$
\theta=\theta_{t e x} \times\left(1-V_{s}\right)
$$

where $\theta$ is moisture content, $\theta_{\text {tex }}$ is mean moisture content for that texture group and $V_{s}$ is the typical proportion of stones encountered in these soil series.

A similar procedure was adopted to estimate the volume of water held in the soil when saturated by adding an additional moisture content to the calculated field capacity value. As there were fewer texture groups with adequate data to determine the moisture content between saturation and field capacity (three for topsoil and five for subsoil) all available data (119 measurements) were amalgamated into topsoil or subsoil, for which the average moisture content held in soils between field capacity and saturation was $15 \%$ for topsoil horizons and $13 \%$ for subsoil horizons regardless of soil texture.

Thus, the soil hydrological properties of saturated moisture content and field capacity needed for the water balance model were derived from existing class pedotransfer functions (MAFF, 1988) and modified by existing Scottish soil hydrological data. This hybrid approach maintained the relative differences between texture groups as shown by the ALC pedotransfer functions. To quantify the total volume of water within each soil profile, the volumes for each horizon were summed. Weighted average values were then calculated for each soil association from the percentage areas of different soils within each association.

\section{WATER BALANCE MODEL CALIBRATION}

Calibration of the water balance model required evaluation of the two parameters controlling flow partitioning, $K V$ and $K L . K V$ is the vertical drainage calibration parameter and $K L$ is the lateral flow calibration parameter. These parameters together control both the amount and rate of transport via the different flow paths. In a situation where the model is to be applied to a specific individual catchment, this calibration could be carried out together with the calibration of other transport parameters, using historic flow data for the catchment. However, in this case, in order to generalise the model to the whole of Scotland and simplify the application to different areas, a calibration technique was developed that related the parameters $K V$ and $K L$ to the Hydrology of Soil Types (HOST) classification (Boorman et al., 1995).
To achieve this, the parameters were evaluated for each soil map unit by comparison with two indices, the base flow index (BFI) and the standard percentage runoff(SPR). These indices have previously been evaluated for different soil types using the HOST methodology. From a one year simulation using the water balance model, the BFI was calculated by summing the weekly losses to groundwater and expressing this as a proportion of the total annual runoff from the soil column:

$$
B F I=\frac{\sum_{t=1}^{52} G W F_{t}}{\sum_{t=1}^{52} F_{t}}
$$
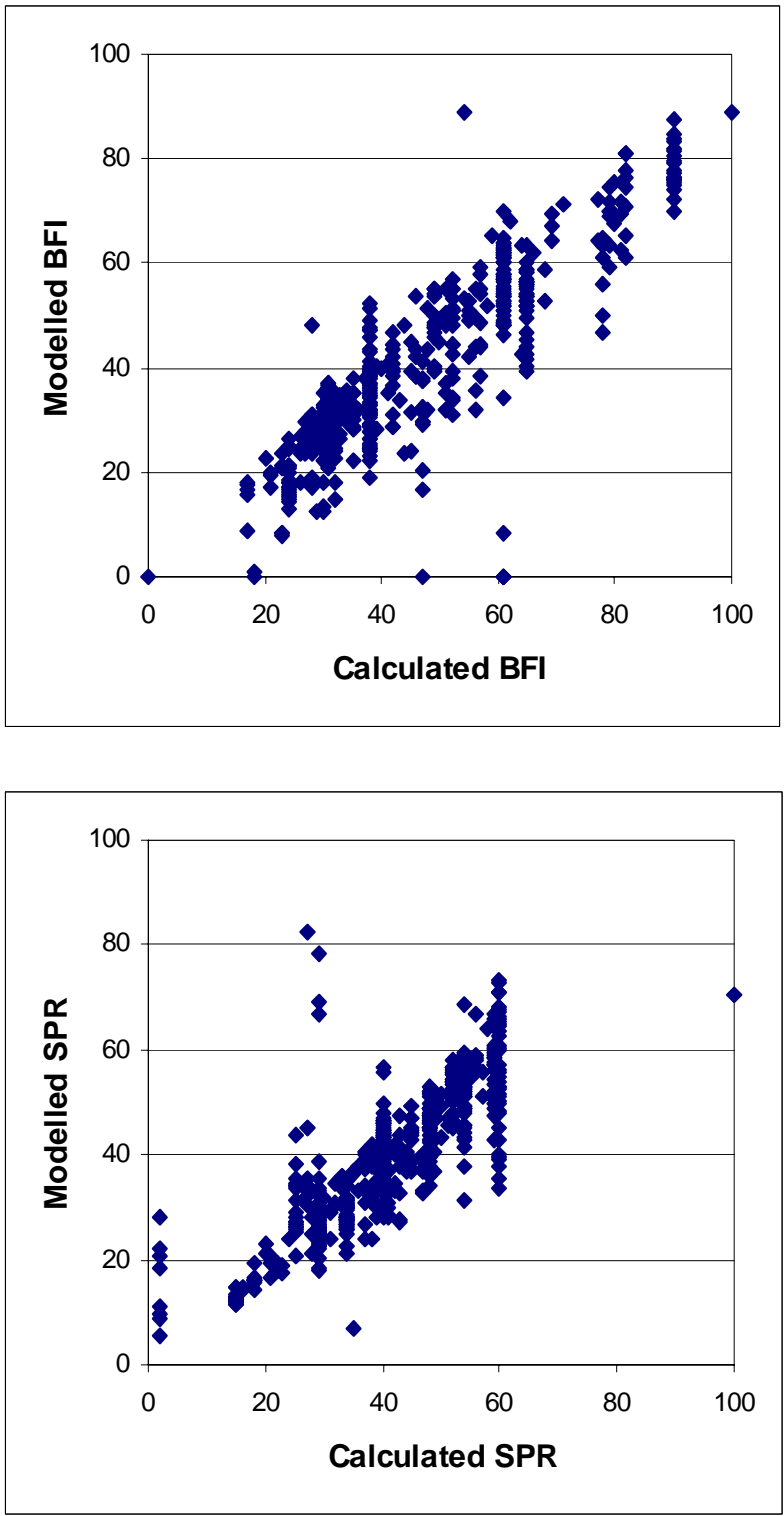

Fig. 3. Comparison of modelled and calculated BFI and SPR, by soil map unit 
Similarly, the SPR was calculated as the annual sum of overland flow and sub-surface flow, expressed as a fraction of the annual rainfall:

$$
S P R=\frac{\sum_{t=1}^{52}\left(O F_{t}+S S F_{t}\right)}{\sum_{t=1}^{52} P_{t}}
$$

These figures were then plotted against a calculated mean BFI and SPR for each soil map unit. The parameters $K V$ and $K L$ were adjusted until a good fit was achieved between the values calculated using the water balance model and those calculated independently for each soil map unit. This is illustrated in Fig. 3.

\section{Model for transport at the catchment scale}

The outputs from the water balance model and $\mathrm{N}$ leaching component are time-series of three flow components, together with fluxes of leached N. The actual fluxes of leached $\mathrm{N}$ are determined by the land cover and its management through their influence on the residual $\mathrm{N}$ in the soil, as well as by the water available for leaching. The flows and losses of $\mathrm{N}$ to surface and groundwaters must then be routed from the soil to the stream, to determine the behaviour of surface waters and the integrated effect of $\mathrm{N}$ pollution over a catchment area. Whereas the water balance model calculations were carried out at a national scale, the transport component of NIRAMS is applied to a specific catchment area for each simulation.

The core dataset for the transport component is a $50 \mathrm{~m}$ resolution digital elevation model. This is used as the basis for defining stream networks, determining directions for flow routing and providing data on the slope of the terrain. The model user can select any catchment by identifying a point on the river network to define the catchment outlet. For the purposes of this analysis, it was assumed that transport within the river system does not significantly alter the flow or affect $\mathrm{N}$ concentrations. Instead, the key processes are assumed to be those involved in transporting $\mathrm{N}$ from the land to the water. This assumption means that the routing model can simply derive a response, in terms of flow and $\mathrm{N}$ flux, for each $50 \mathrm{~m}$ grid cell that would be observed within the stream network. The approach follows a methodology similar to that developed in Dunn et al. (1998).

A different routing function was necessary to describe the different rates of transport and degrees of mixing that occur between the near surface flows and the groundwater flows. The overland flow was combined with the sub-surface flow for routing purposes, partly because there will be a considerable amount of mixing between the two flow components before the water reaches the stream network. In addition, at a weekly time resolution, it is difficult to distinguish between the two processes in terms of flow rates.

\section{SUB-SURFACE ROUTING}

The equation to describe sub-surface flow routing is based on the philosophy adopted in Dunn et al. (1998). This assumes that most of the water reaches the stream network by some form of preferential flow pathway, such as agricultural drainage, soil macro-pores or rill flow. The transport time by this flow is assumed to be insignificant by comparison with that through the soil to reach a preferential flow path. This implies that the sub-surface flow rate is largely independent of the location of a cell in the catchment, in relation to the stream network or catchment-scale topography. Instead, it is assumed to be dependent on the density of the preferential flow pathway network and local variations in topography.

The combined overland and sub-surface flow losses, calculated using the water balance model, are added to a sub-surface storage, SSTORE (m). Routed flows to the stream network are calculated for each cell, as a function of this storage. Using the same formulation as in Dunn et al. (1998), the flow can be calculated as:

$$
Q S_{t}=K S R \times S S T O R E_{t}^{2} \times W^{2}
$$

where, $Q S_{t}$ is the sub-surface flow for a particular cell at time $\mathrm{t}\left(\mathrm{m}^{3} \mathrm{~s}^{-1}\right), K S R$ is a calibration parameter for sub-surface routing $\left(\mathrm{m}^{-1} \mathrm{~s}^{-1}\right)$ and $W$ is the cell width $(\mathrm{m})$

The model assumes that $\mathrm{N}$ is carried with the flow of water. The initial condition for the sub-surface store is zero, so that the only mixing effect within the sub-surface occurs with relatively new water. All water within SSTORE is assumed to be fully mixed.

\section{GROUNDWATER ROUTING}

The basis for groundwater flow-routing is assumed to be Darcian. The groundwater component, calculated using the water balance model, is added to a groundwater storage, GWS (m). Routed groundwater flows are then calculated for each cell, as a function of this storage, such that:

$$
Q G W_{t}=K G W R \times G W S_{t} \times H S L D \times W \times F
$$

where, $Q G W_{t}$ is the groundwater flow at time $\mathrm{t}\left(\mathrm{m}^{3} \mathrm{~s}^{-1}\right)$, $K G W R$ is a groundwater routing calibration parameter $\left(\mathrm{m} \mathrm{s}^{-1}\right)$ and HSLD is the hill slope from the cell to the stream (-). To apply this on a cell by cell basis, the influence of upstream 
flows and topography are incorporated by weighting the flows for each cell by the factor $F$ :

$$
F=\frac{H S L D}{H S L D+(S L U \times A R U)}
$$

where, $S L U$ is the slope into a cell from above (-) and $A R U$ is the number of cells contributing to flow into the cell from above (-)

This equation essentially means that, for a cell with a large contributing area and where the flow gradient into the cell is steep relative to the gradient out of the cell, there will be large water storage within that cell. The rate of outflow from that cell will be less because of the low down-slope gradient. However, the actual volumes of flow may be great because of its large water storage. The large water storage is accounted for by incorporating the up-slope contributing area and gradient in the calculation of initial conditions (described below).

For each point on the stream network, a catchment analysis is carried out to determine the area of the land draining to that point. The equivalent contribution of groundwater flow from each cell to flow in the stream, $Q G W C\left(\mathrm{~m}^{3} \mathrm{~s}^{-1}\right)$ is then calculated as:

$$
Q G W C_{t}=\frac{Q G W_{t}}{N C}
$$

where, $N C$ is the number of cells draining to the stream at that point (-)

The initial conditions for the size of the groundwater store and its $\mathrm{N}$ content are extremely important because of their effect in smoothing the groundwater variability and in sustaining stream flows and concentrations during dry periods. A methodology was developed to estimate the magnitude of the groundwater store by taking into account the topographic location of each cell as well as the Base Flow Index (Boorman et al., 1995) of the soil at that point. Together, these factors provide a surrogate for relative depth, which can be calibrated to give an absolute value. The function used was:

$$
G W S_{0}=K I C \times B F I \times \frac{H S L D+(S L U \times A R U)}{H S L D^{2}}
$$

where $K I C$ is a calibration parameter $(\mathrm{m})$ and $B F I$ is the baseflow index for the soil in each cell (-). Other variables are as defined previously. An upper limiting value of $5000 \mathrm{~mm}$ is used to avoid unrealistic extreme figures in areas with large up-slope areas and gentle slopes into the stream network. The basic pattern resulting from the initial condition imposed is conceptually realistic, with the greatest storage along riparian zones and areas of low relief.

The initial condition for $\mathrm{N}$ content of the groundwater store was estimated using results from a study that evaluated the risk of nitrate contamination of groundwaters in Scotland (Lilly et al., 2001); this was a map that categorised Scotland into a set of risk classes for groundwater $\mathrm{N}$ concentrations. These risk classes were based on a linear regression between actual values of $\mathrm{N}$ concentrations from data collected by SEPA and modelled values. Thus, the map could be used to derive predicted $\mathrm{N}$ concentrations for groundwaters throughout Scotland and to give estimates of initial conditions for groundwater $\mathrm{N}$ concentrations for NIRAMS. Flows and $\mathrm{N}$ leached to groundwater from the soil are added to the groundwater store for each cell at each time-step, where they are assumed to mix fully with the existing store.

\section{CATCHMENT FLOW AND N CONCENTRATIONS}

The contributions from each cell in the catchment to routed sub-surface / overland flow and to groundwater flow are combined by simple addition to give the total catchment flows. Similarly the fluxes of $\mathrm{N}$ carried with the sub-surface and groundwater flows are summed to give the total $\mathrm{N}$ flux in the stream. The stream flow is used to convert this figure into a concentration of $\mathrm{N}$.

\section{Model Testing}

\section{PARAMETER CALIBRATION}

To test the model, simulations were first carried out for a one year period using historic data from Aug 1997-Aug 1998 for the same eight catchments used to compare N leaching predictions in Dunn et al. (2004). The physical characteristics of these eight catchments are summarised in Table 2. Daily flow data and spot measurements of stream $\mathrm{N}$ concentration, at approximately monthly intervals, were provided by the Scottish Environment Protection Agency and helped to calibrate the parameters for flow routing, $K S R$, $K G W R$ and $K I C$. The sensitivity of the results to the value of the $\mathrm{N}$ leaching parameter, $K N L$, was also investigated.

The calibration parameter for sub-surface / overland flow routing, $K S R$, was evaluated by comparing the predicted stream flows with observed weekly mean flows during periods of high flow following rainfall events. A value of $\mathrm{KSR}=4.05 \mathrm{e}^{-04} \mathrm{~m}^{-1} \mathrm{~s}^{-1}$ gave a good fit for all of the eight catchments.

Calibration of the parameters controlling the groundwater response, $K G W R$ and $K I C$ involved examination of the longterm behaviour of the model in addition to a simple comparison with the observed baseflow responses of the rivers. A mis-match between the recharge of the groundwater stores and the rate of groundwater flow to the stream will result in a gradual change with time of the groundwater flow. 
Table 2. Summary of characteristics of NIRAMS test catchments

\begin{tabular}{llllllll}
\hline Catchment & $\begin{array}{l}\text { Area } \\
\mathrm{km}^{2}\end{array}$ & $\begin{array}{l}\text { Av. ann. } \\
\text { rain mm }\end{array}$ & $\begin{array}{l}\text { Elev. range } \\
\text { (mean) } m\end{array}$ & \% Arable & $\begin{array}{c}\text { \% Improved } \\
\text { pasture }\end{array}$ & $\begin{array}{l}\text { \% Freely } \\
\text { drained soil }\end{array}$ & $\begin{array}{l}\text { \%Poorly } \\
\text { drained soil }\end{array}$ \\
\hline Ythan & 526 & 826 & $4-380(107)$ & 88 & 5 & 69 & 18 \\
N Esk & 740 & 1074 & $15-929(313)$ & 26 & 8 & 37 & 56 \\
Earn & 738 & 1397 & $7-979(284)$ & 24 & 6 & 41 & 36 \\
Eden & 318 & 799 & $9-520(110)$ & 75 & 5 & 62 & 25 \\
Tyne & 313 & 713 & $15-527(175)$ & 65 & 13 & 31 & 54 \\
Urr & 200 & 1340 & $2-423(156)$ & 0 & 48 & 33 & 66 \\
Irvine & 480 & 1228 & $1-383(144)$ & 0.4 & 66 & 10 & 89 \\
Carron & 149 & 2620 & $4-1043(365)$ & 0 & 1 & 39 & 61 \\
\hline
\end{tabular}

Eventually, by adjustments to the groundwater stores within the model, equilibrium will be reached. However, an alternative approach is to modify the groundwater parameters, $K G W R$ and $K I C$, such that the initial conditions give a better balance between recharge and flow. This will reduce significantly the time taken for the model to reach a steady-state. Modifying KIC affects only the initial groundwater storage for the model, whereas a modification to $K G W R$ adjusts the rate of groundwater flow throughout the simulation. After running a number of simulations with cycled meteorological data, values for the parameters of KIC $=0.0015 \mathrm{~m}$ and $\mathrm{KGWR}=0.029 \mathrm{~m}^{3} \mathrm{~s}^{-1}$ were found to give a calibration acceptable for each of the eight catchments.

In Dunn et al. (2004), comparisons of the behaviour of the NLEAP leaching function with experimental data indicated that a value of $K N L=0.7$ gave a more realistic $\mathrm{N}$ loss rate than the value of 1.2 established by Shaffer et al. (1994). To pursue this issue further, simulations for the Eden and Irvine catchments investigated how different values for KNL affected the predictions of stream $\mathrm{N}$ concentrations. The Eden consists of largely freely-drained soils whilst the Irvine soils are largely poorly-drained. The test simulations are in Fig. 4, where measured concentrations of stream $\mathrm{N}$ are also shown. At the catchment scale, using a value of $K N L=0.7$ does not permit sufficient leaching from the soil. Hence, the predicted stream concentrations were too low and a high level of residual $\mathrm{N}$ was left in the soil at the end of the year. For the Eden catchment, the predicted mean stream $\mathrm{N}$ concentration was reduced from 6.2 to $4.8 \mathrm{mg} \mathrm{l}^{-1}$ and, for the Irvine, from 1.8 to $1.4 \mathrm{mg} \mathrm{l}^{-1}$. This finding highlights the potential problem of using plot-scale experimental data to parameterise catchment-scale modelling. The plot-scale observations provided only one set of measurements which proved, in this instance, to be non-representative of the integrated response observed in the stream.

The results of the calibrated simulations for 1997-1998
R Eden at Kembach

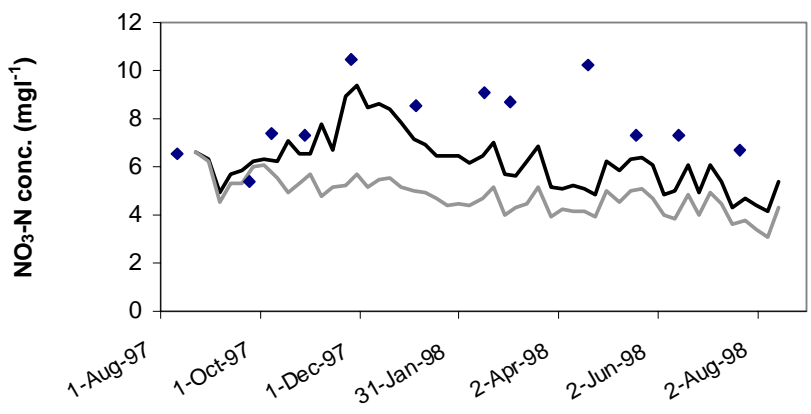

R Irvine at Irvine

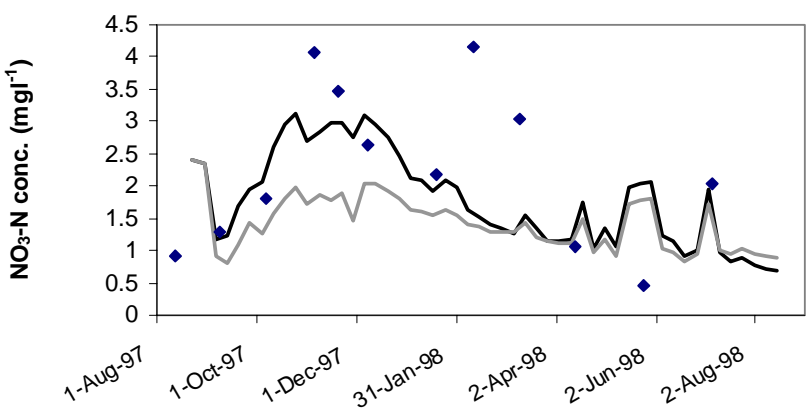

Figure 4: Comparison of predicted streamwater $N$ concentrations for calibration simulations for $R$ Eden and Irvine using values of $K N L=1.2$ (black line) and $K N L=0.7$ (grey line). Observed streamwater concentrations shown by markers

(with a value of $K N L=1.2$ ), summarised in Table 3 for flows and Table 4 for $\mathrm{N}$, have been compared with measured statistics for each of the eight catchments. The efficiency measure for the flow simulations is based on the Nash and Sutcliffe (1970) criterion calculated for weekly mean flows. This measure compares the predicted flow against the measured flow using the measured mean flow as a benchmark, with a value of 0 indicating that the model is no better than using the mean flow as a predictor, and a 
Table 3. Summary of flow statistics for calibration simulations (1997-98) for test catchments

\begin{tabular}{lccc}
\hline Catchment & Efficiency & $\begin{array}{c}\text { Calculated } \\
\text { runoff mm }\end{array}$ & $\begin{array}{l}\text { Measured } \\
\text { runoff } m m\end{array}$ \\
\hline Ythan & 0.73 & 508 & 637 \\
N Esk & 0.82 & 755 & 914 \\
Earn & 0.64 & 912 & 1198 \\
Eden & 0.85 & 428 & 403 \\
Tyne & 0.40 & 377 & 294 \\
Urr & 0.67 & 955 & 940 \\
Irvine & 0.84 & 904 & 787 \\
Carron & 0.68 & 1685 & 2242 \\
\hline
\end{tabular}

value of 1 indicating perfect prediction. In general, the simulations were very successful at reproducing the weekly mean flows. The poorest efficiency value of 0.4 for the Tyne catchment reflects the low net runoff in this catchment so that errors in the predicted flows are more accentuated, relative to the mean flow, than in wetter catchments, such as the Carron, Earn and N Esk, all of which under-predicted the runoff. This is almost certainly due to under-estimating precipitation in these more mountainous catchments, in the absence of any elevation weighting in the rainfall interpolation scheme.

Table 4 shows that, in general, the predictions of stream $\mathrm{N}$ concentration were successful. Ranking the eight catchments in order of mean $\mathrm{N}$ concentration, only the predictions for the Urr catchment are out of place, with an under-estimate of $1.5 \mathrm{mg}^{-1}$ for the mean $\mathrm{N}$ concentration. Ranges of predicted and measured $\mathrm{N}$ concentrations for each catchment are also comparable.

\section{MODEL VALIDATION}

Following the calibration simulations, the NIRAMS model was applied using the same parameter values, to the same eight catchments, for a five-year simulation from August 1989-August 1994, using a preliminary year's run on 198990 data to provide the initial conditions. The results of these simulations are presented in Figs. 5 and 6. Comparisons of predicted weekly mean flows with measurements show very good agreement for each of the catchments, as is confirmed by the Nash and Sutcliffe efficiency values for the simulations quoted in Table 5. For four of the catchments, the efficiency values equal or exceed those from the calibration simulations. Only the N Esk validation simulation is significantly poorer in terms of flow prediction. Figure 5 also shows that the shapes of the hydrographs are well reproduced by the model. In the Ythan catchment, the predicted speed of recession is slightly too fast and baseflow levels are slightly too low; this suggests a slight error in the flow partitioning, but this is not observed in the other catchments. As with the calibration simulations, the calculated mean annual runoff compares well with the measured values for all catchments except the Carron, where there is a substantial under-estimate.

The predictions of stream $\mathrm{N}$ concentrations also match observations very well in terms of their mean values (Table $6)$. The time-series plots in Fig. 6 demonstrate that the simulations reproduce the broad seasonal trends in variation of stream $\mathrm{N}$ concentrations, but there are some consistent differences between predictions and observations. As is to be expected, the week to week variability is less well modelled due to the simplifications in the NIRAMS model in terms of process representation and temporal resolution. However, the ranges of $\mathrm{N}$ concentrations are reasonable. For several of the catchments, the model predicts a gradual increase in concentration with decreasing baseflow in summer; in practice a decrease is observed. This may well be caused by denitrification, as contributions to flow during this period will be primarily from groundwater containing old $\mathrm{N}$ leachate.

Table 4. Summary of N statistics for calibration simulations (1997--98) for test catchments

\begin{tabular}{lcclc}
\hline \multirow{2}{*}{$\begin{array}{l}\text { Catchment } \\
\end{array}$} & \multicolumn{2}{c}{$\begin{array}{c}\text { Mean } N \text { concentration }\left(\mathrm{mg} l^{-1}\right) \\
\text { Calculated }\end{array}$} & Measured & \multicolumn{2}{c}{$\begin{array}{c}\text { Concentration range }\left(\mathrm{mg} l^{-1}\right) \\
\text { Calculated }\end{array}$} & Measured \\
\hline Ythan & 7.0 & 8.4 & $3.2-12.1$ & $6.2-10.1$ \\
N Esk & 2.1 & 2.2 & $0.9-3.6$ & $0.5-4.2$ \\
Earn & 1.6 & 1.6 & $0.7-3.7$ & $0.3-3.9$ \\
Eden & 6.2 & 7.9 & $4.2-9.4$ & $5.4-10.5$ \\
Tyne & 4.9 & 5.6 & $3.0-7.3$ & $3.9-7.8$ \\
Urr & 1.4 & 2.9 & $0.5-3.2$ & $1.4-4.0$ \\
Irvine & 1.8 & 2.2 & $0.7-3.1$ & $0.5-4.1$ \\
Carron & .09 & .05 & $.04-0.4$ & $.03-0.1$ \\
\hline
\end{tabular}


R Carron at New Kelso
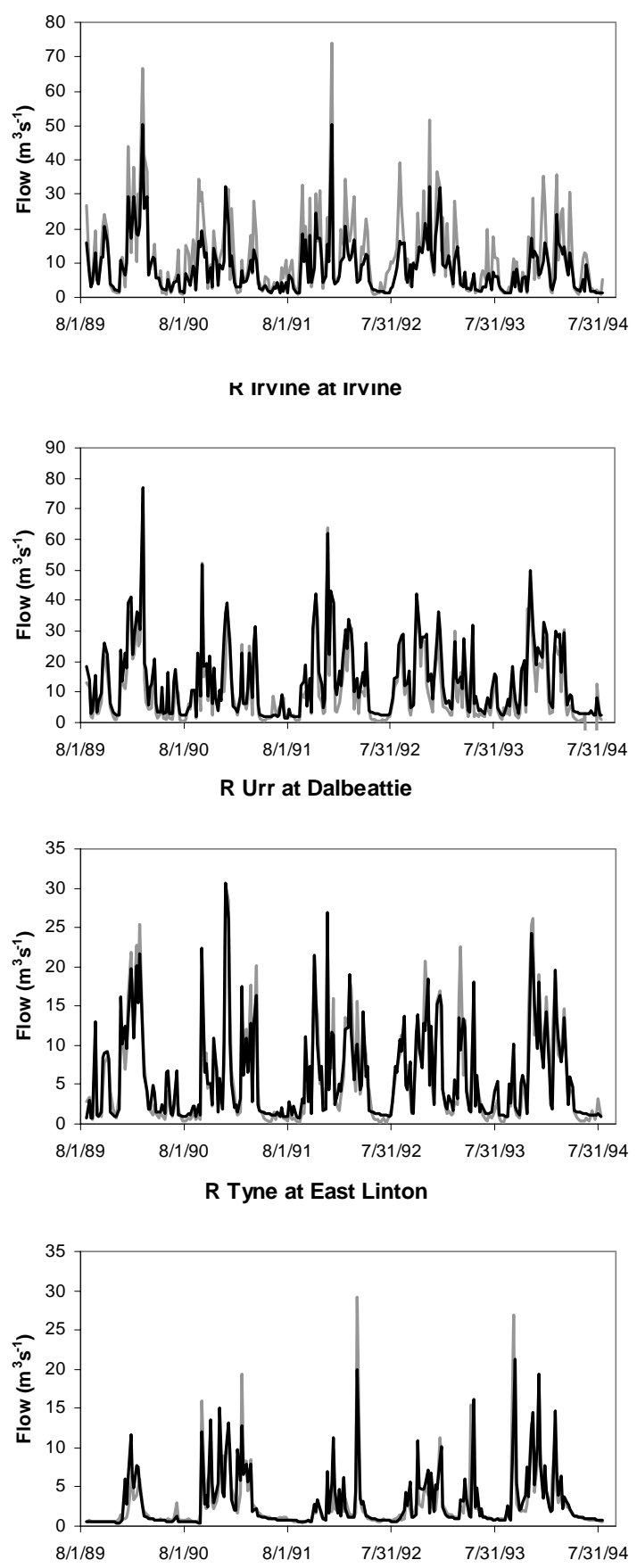

R Ythan at Ellon
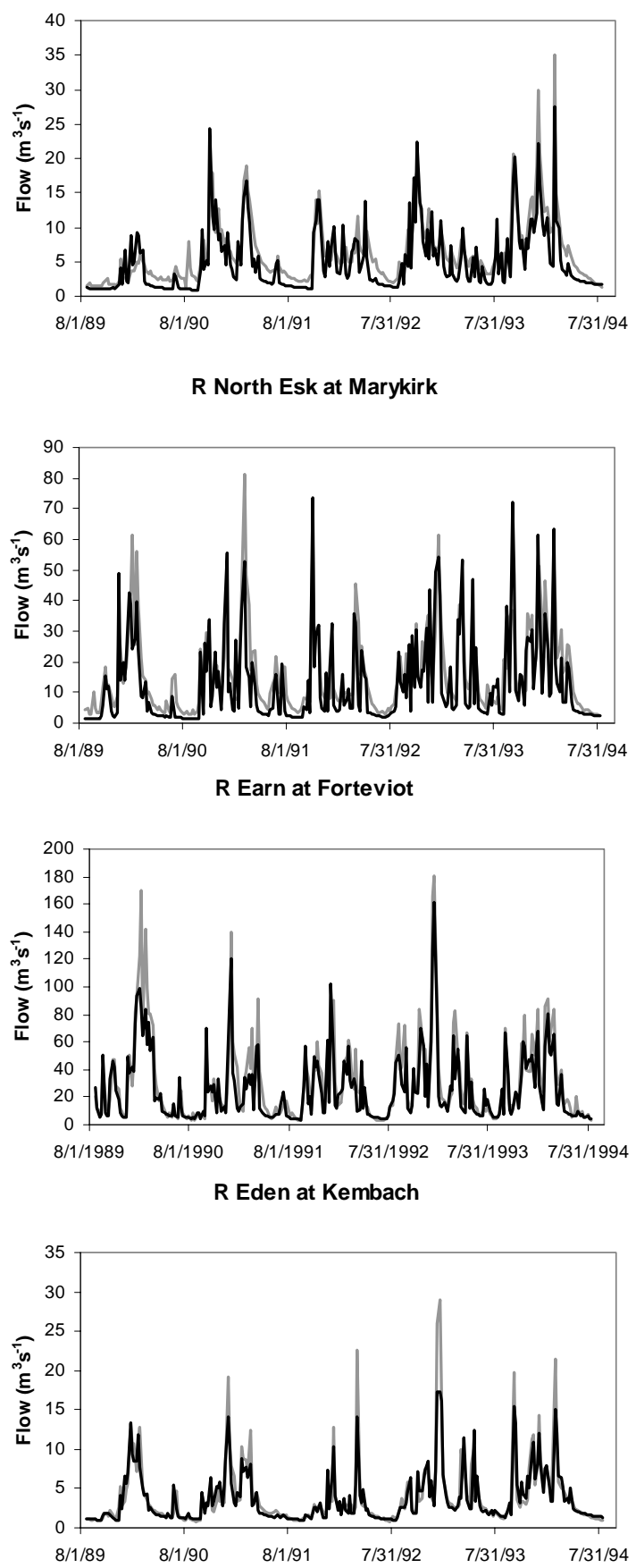

Fig. 5. Comparison of predicted and measured flows for validation simulations for eight catchments (predicted flows in black, observed flows in grey)

The predictions for the Eden catchment suggest a decrease in mean concentration for the last two years of the simulation but this was not observed in practice. Examination of the flow predictions through the simulation shows a gradual increase in the groundwater flow contribution; the initial condition for the groundwater store may have been too low for the Eden catchment. Where most of Scotland has limited deep groundwater resources, in the Eden catchment, a significant aquifer in Upper Old Red Sandstone contributes to river flows. Therefore, it is not surprising that the value for the calibration parameter KIC that is appropriate for other catchments in Scotland does not define ideal initial conditions for the Eden catchment.

The poorest set of predictions for the validation 
R Carron at New Kelso
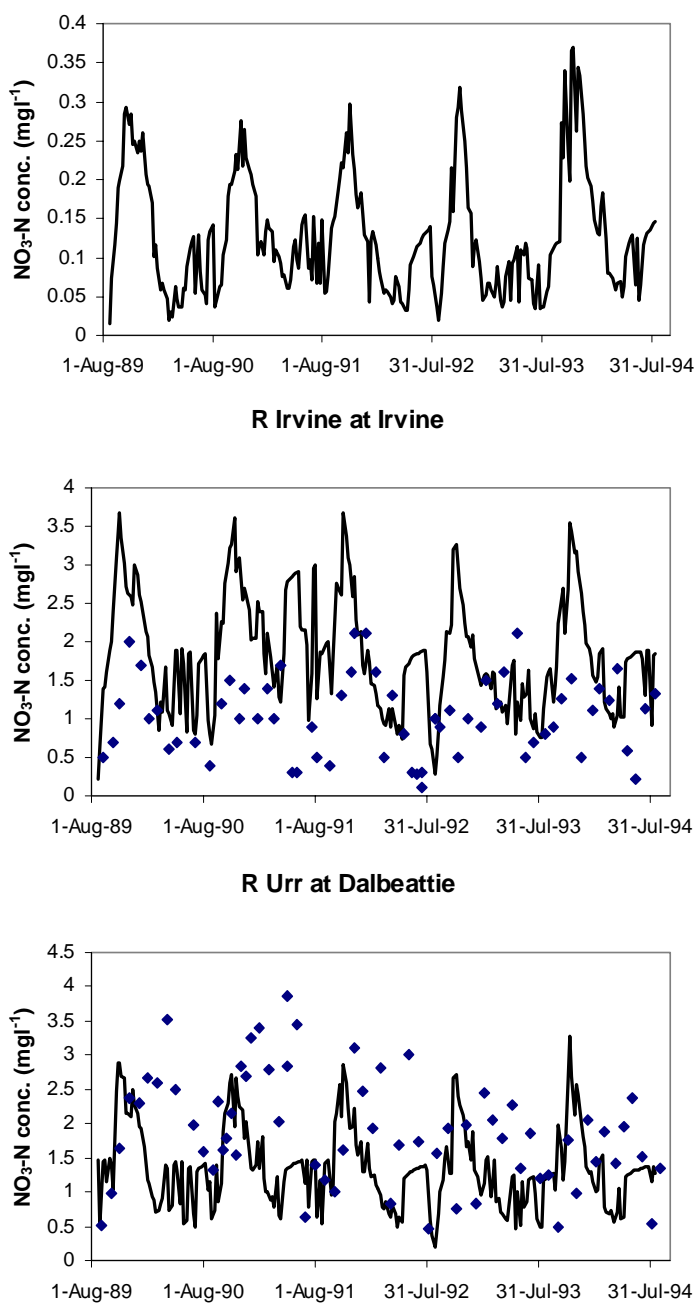

R Tyne at East Linton

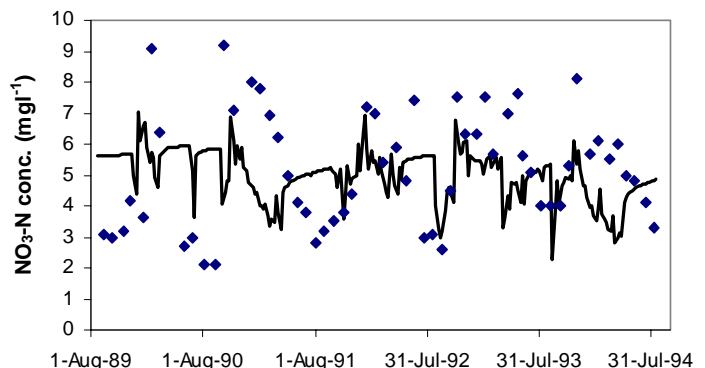

R Ythan at Ellon

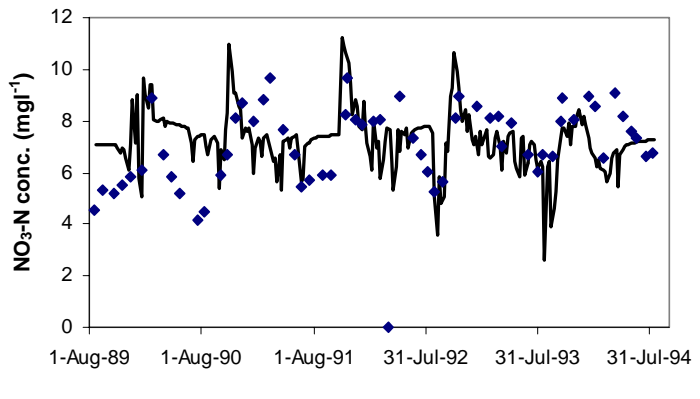

R North Esk at Marykirk

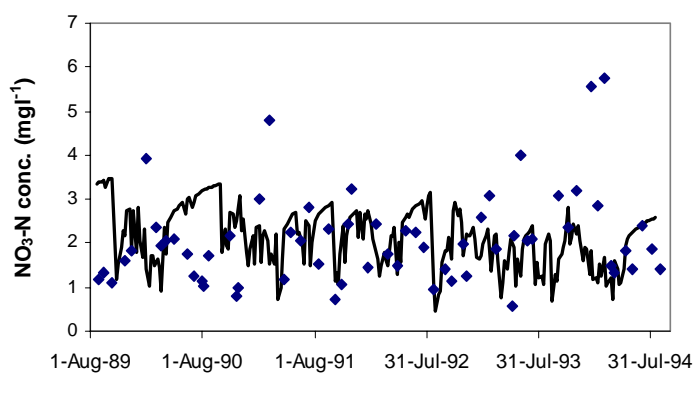

R Earn at Forteviot

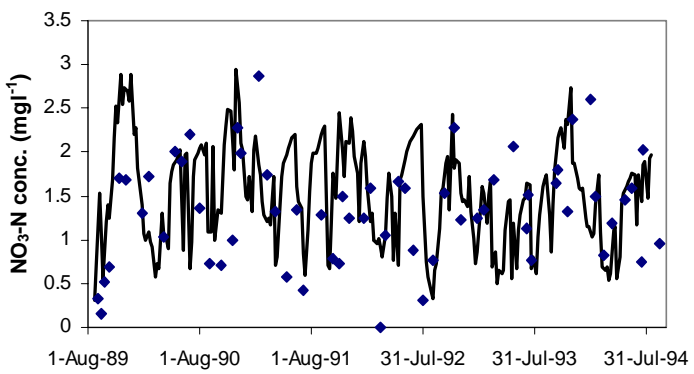

R Eden at Kembach

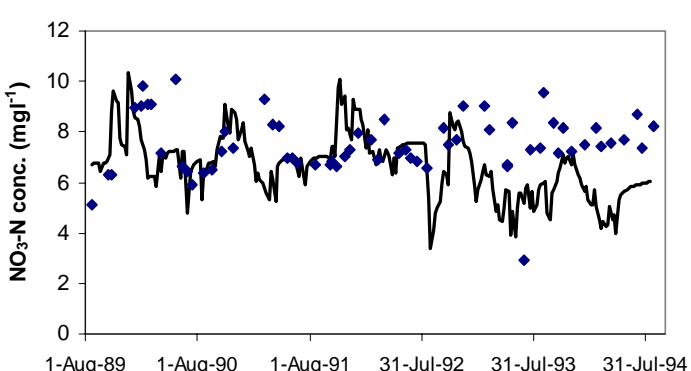

Fig. 6. Comparison of predicted and measured streamwater $N$ concentrations for validation simulations for eight catchments (predicted concentrations as line, observed concentrations as markers). (No observed data were available for the $R$ Carron.)

simulations, in terms of mean concentration, was for the Irvine catchment, although the temporal variability was well predicted. This result is odd, as the mean observed concentration for the calibration period was significantly higher and gave a good match with the model predictions.

\section{Discussion and conclusions}

The test simulations of NIRAMS demonstrate that the model provides a practical methodology for predicting surface water $\mathrm{N}$ concentrations anywhere in Scotland. The model was developed entirely within the GIS package ArcView 3.2 using Avenue, ArcView's programming and 
Table 5. Summary of flow statistics for validation simulations (1989-94) for test catchments

\begin{tabular}{llcc}
\hline Catchment & Efficiency & $\begin{array}{c}\text { Calculated mean annual } \\
\text { runoff mm }\end{array}$ & $\begin{array}{c}\text { Measured mean annual } \\
\text { runoff mm }\end{array}$ \\
\hline Ythan & 0.69 & 298 & 370 \\
N Esk & 0.53 & 616 & 669 \\
Earn & 0.78 & 1102 & 1327 \\
Eden & 0.82 & 372 & 392 \\
Tyne & 0.63 & 306 & 282 \\
Urr & 0.86 & 952 & 932 \\
Irvine & 0.84 & 901 & 721 \\
Carron & 0.66 & 1786 & 2504 \\
\hline
\end{tabular}

Table 6. Summary of N statistics for validation simulations (1989-94) for test catchments

\begin{tabular}{|c|c|c|c|c|}
\hline \multirow[t]{2}{*}{ Catchment } & \multicolumn{2}{|c|}{ Mean $N$ concentration $\left(\mathrm{mgl}^{-1}\right)$} & \multicolumn{2}{|c|}{$N$ concentration range $\left(\mathrm{mgl}^{-1}\right)$} \\
\hline & Calculated & Measured & Calculated & Measured \\
\hline Ythan & 7.3 & 7.1 & $2.6-11.2$ & $4.2-9.7$ \\
\hline N Esk & 2.1 & 2.1 & $0.5-3.5$ & $0.6-5.7$ \\
\hline Earn & 1.5 & 1.3 & $0.3-2.9$ & $0.1-2.9$ \\
\hline Eden & 6.7 & 7.5 & $3.4-10.4$ & $3.0-10.1$ \\
\hline Tyne & 5.0 & 5.2 & $2.3-7.0$ & $2.1-9.2$ \\
\hline Urr & 1.4 & 1.9 & $0.2-3.3$ & $0.5-3.9$ \\
\hline Irvine & 1.8 & 1.0 & $0.2-3.7$ & $0.1-2.1$ \\
\hline Carron & .13 & $\mathrm{~N} / \mathrm{A}$ & $.01-0.4$ & N/A \\
\hline
\end{tabular}

customisation language, and includes a user-friendly interface. To minimise simulation times for the model, many of the spatial data have been pre-processed to a format where they are used directly within the model. This applies, for example, to 'flow direction' and 'flow accumulation' calculations within the flow routing component of the model. In addition, the water balance model has been pre-run for the whole of Scotland, using a weekly time-step, for five years of historic data from 1989-1994. This created output grids of the three flow components and proportion of $\mathrm{N}$ leached for each week of the simulation. These data are clipped out for a particular catchment simulation, such that the real time modelling needs to run only the routing component of the model for the selected catchment. Consequently the model can be applied easily to different catchment areas.

The tests have shown that acceptable simulations can be achieved on a range of very different catchments without re-calibration of parameters. Whilst fine-tuning of parameters might improve individual simulations, the model can be applied to ungauged catchments or coastal gap areas with confidence that an acceptable simulation will be achieved. Such applications are of particular value for general screening purposes, to identify where high streamwater $\mathrm{N}$ concentrations may occur, so that more detailed monitoring or modelling studies can be focused in appropriate areas. This is possible with NIRAMS because many of the controlling factors have been built into the model. This includes, for example, estimates of initial conditions for groundwater $\mathrm{N}$ concentrations and the use of the BFI and SPR statistics to calibrate parameters determining the relative flow proportions at different times. The modelling also demonstrates that large scale $\mathrm{N}$ modelling can be carried out successfully despite limitations in the availability of data at the national scale and with great simplification of $\mathrm{N}$ cycle processes. One of the most important controls in modelling is the precipitation input, which exhibits extremely high variability across Scotland. Although data from as many as 700 raingauges were used in the interpolation of the data, there is still considerable uncertainty in values for parts of the country. This is particularly so for north-west Scotland, where raingauges are relatively sparse and are mostly located at low altitudes, so that little information about precipitation in the mountains is available. The model simulations highlighted this uncertainty, showing a substantial under-estimate of runoff in the Carron catchment in north-west Scotland, probably caused by an under-estimation of precipitation. NIRAMS 
does not currently account for snow processes. Although snow can contribute significantly to the water balance in some winters in certain parts of Scotland, snowfall and snowpack persistence are generally less important in the lowland agricultural areas. As the model operates at a weekly temporal resolution it would be far less sensitive to the effect of snowfall on timing of runoff than a daily model would be, and the impact on predicted seasonal variability of nitrate concentrations could be expected to be low. In terms of the general prediction capability of the NIRAMS model for identifying areas at risk from $\mathrm{N}$ pollution, the errors in precipitation in the north-west of the country and in the mountains will be relatively insignificant. The $\mathrm{N}$ inputs to these areas are very low and losses of $\mathrm{N}$ are much diluted by the high levels of effective rainfall. For catchments in other areas of Scotland, the hydrological validation demonstrated that the water balance is modelled to an acceptable level of accuracy.

At present, NIRAMS has limitations for long-term modelling of $\mathrm{N}$ losses because it assumes a steady-state situation with respect to soil $\mathrm{N}$ content. The residual $\mathrm{N}$ available for leaching during the year is calculated on the basis of agricultural activities in the preceding season. To adapt the model to study long-term changes in $\mathrm{N}$, aspects, notably mineralisation and immobilisation, would have to be built in, to carry over unleached excess residual $\mathrm{N}$ from one year's simulation to the next.
More detailed analysis of the catchment simulations reveal further information about the dominant controls on streamwater $\mathrm{N}$ concentrations in the different catchments. In Fig. 7, the percentage of flow contributed at any time from sub-surface and groundwater routing is shown for the Irvine and Ythan catchments, together with the predicted $\mathrm{N}$ concentrations of these waters, as well as the predicted streamwater $\mathrm{N}$ concentration. Whereas runoff from the Irvine catchment is frequently dominated by sub-surface flow, in the Ythan catchment groundwater flow is more often dominant. This is reflected in the streamwater $\mathrm{N}$ concentrations where, for the Irvine catchment, the streamwater follows the pattern of the sub-surface concentrations and, in the Ythan catchment, the streamwater mirrors the groundwater concentrations. The measurements for the two catchments confirm that these effects are reasonable. The results highlight the importance of transport in controlling streamwater $\mathrm{N}$ concentrations. However, the timing of leaching, determined by drainage from the soil, is also important in generating the signals of sub-surface and groundwater concentrations. The calibration tests to vary the value of the leaching rate parameter, $K N L$, demonstrated how the streamwater response is damped by too low a value of this parameter. Hence, streamwater $\mathrm{N}$ concentrations are determined by, both supply and transport, rather than being limited by either.
R Irvine at Irvine
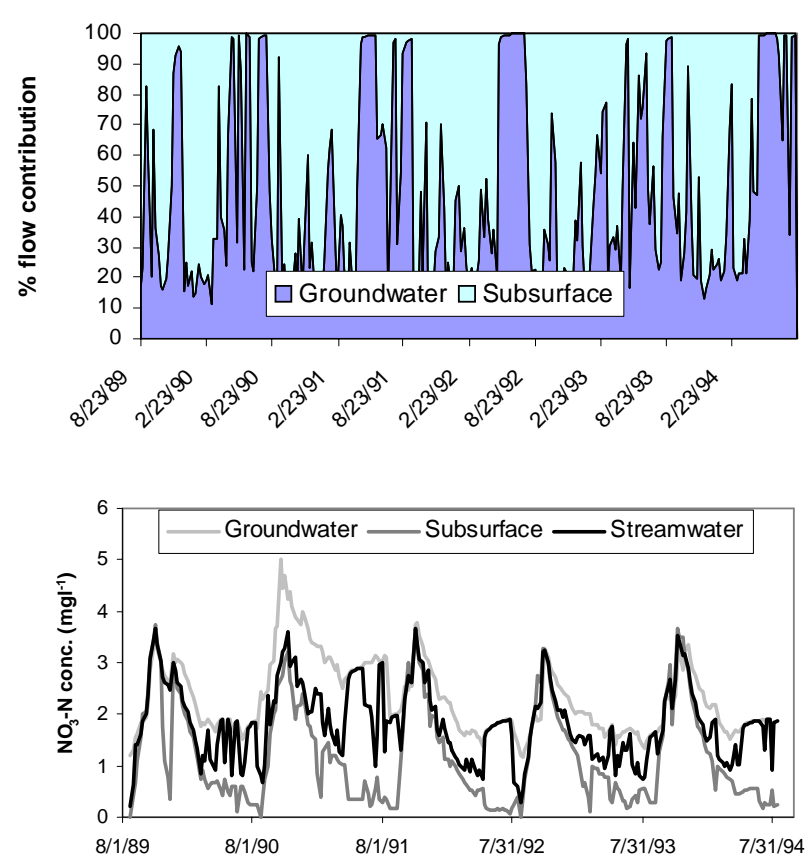

$\mathbf{R}$ Ythan at Ellon
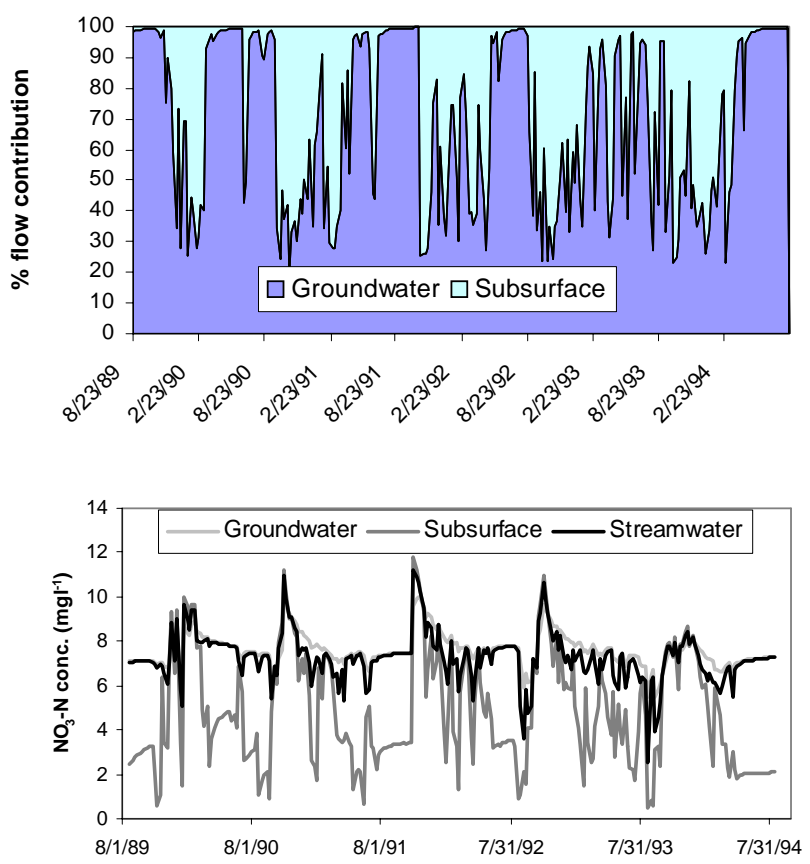

Fig. 7. Percentage flow contributions and $N$ concentrations for sub-surface and groundwater flows in the Irvine and Ythan catchments 


\section{Acknowledgements}

This research was funded by the Scottish Executive Environment and Rural Affairs Department.

\section{References}

Allen, R.G., Pereira, L.S., Raes, D. and Smith, M., 1998. Crop evapotranspiration - Guidelines for computing crop water requirements. FAO Irrigation and drainage paper 56. FAO, Rome, Italy.

Andersen, H.R., Pedersen, M.L., Jorgensen, O. and Kronvang, B., 2001. Analysis of the hydrology and flow of nitrogen in 17 Danish catchments. Water Sci. Technol., 44, 63-68.

Anthony, S., Quinn, P. and Lord, E., 1996. Catchment scale modeling of nitrate leaching. Aspects of Applied. Biology, 46: Modelling in applied biology. Spatial aspects. 23-32.

Beaujouan, V., Durand, P. and Ruiz, L., 2001. Modelling the effect of the spatial distribution of agricultural practices on nitrogen fluxes in rural catchments. Ecol. Model., 137, 93-105.

Boorman, D.B.,Hollis, J.M. and Lilly, A., 1995.Hydrology of soil types: a hydrologically- based classification of the soils of the United Kingdom. Institute of Hydrology Report No. 126. Centre for Ecology and Hydrology, Wallingford, UK. 137pp.

Burns, I.G., 1980. A simple model for predicting the effects of winter leaching of residual nitrate on the nitrogen fertilizer need of spring crops. J Soil Sci., 31, 187-202.

Christopherson, N., Neal, C., Hooper, R.P., Vogt, R.D. and Andersen S., 1990. Modeling streamwater chemistry as a mixture of soilwater end-members. A step towards second generation acidification model. $J$ Hydrol, 116, 307-320.

Cooper, D.M. and Roberts, G., 1996. Nitrate leaching from a small catchment in central England. Soil Use Manage., 12, 181-189.

Crabtree, R., Dunn, S.M., Chalmers, N. and Stalham, M., 2002. Evaluating the economic impact of irrigation controls. Final Report for SEERAD, Macaulay Institute, Aberdeen, UK.

Creed, I.F., Band, L.E., Foster, N.W., Morrison, I.K., Nicolson, J.A., Semkin, R.S. and Jeffries, D.S., 1996. Regulation of nitrate$\mathrm{N}$ release from temperate forests: A test of the $\mathrm{N}$ flushing hypothesis. Water Resour. Res., 32, 3337-3354.

Dunn, S.M. and Mackay, R., 1995. Spatial variation in evapotranspiration and the influence of land use on catchment hydrology. J Hydrol., 171, 49-73.

Dunn, S.M., McAlister, E. and Ferrier, R.C., 1998. Development and application of a distributed catchment-scale hydrological model for the River Ythan, N.E. Scotland, Hydrol. Process., 12, 401-416.

Dunn, S.M., Stalham, M., Chalmers, N. and Crabtree, B., 2003. Adjusting irrigation abstraction to minimise the impact on stream flow in the East of Scotland. J Environ. Manage, 68, 95-107.

Dunn, S.M., Vinten, A.J.A., Lilly, A., DeGroote, J. and McGechan, M., 2004. Nitrogen risk assessment model for Scotland: I. Nitrogen leaching. Hydrol. Earth Syst. Sci., 8, 191-204.

Goovaerts, P., 2000. Geostatistical approaches for incorporating elevation into the spatial interpolation of rainfall. J. Hydrol., 228, 113-129.

Leon, L.F., Soulis, E.D., Kouwen, N. and Farquhar, G.J., 2001. Nonpoint source pollution: a distributed water quality modelling approach. Water Res., 35, 997-1007.

Lilly, A., Malcolm, A. and Edwards, A.C., 2001. Development of a methodology for the designation of groundwater Nitrate Vulnerable Zones in Scotland. Final Report for SEERAD, Macaulay Institute, Aberdeen, UK.
Lin, B.L., Sakoda, A., Shibasaki, R. and Suzuki, M., 2001. A modelling approach to global nitrate leaching caused by anthropogenic fertilisation. Water Res., 35, 1961-1968.

Lord, E.I. and Anthony, S.G., 2000. MAGPIE: A modelling framework for evaluating nitrate losses at national and catchment scales. Soil Use Manage., 16, 167-174.

MAFF, 1988. Agricultural land classification of England and Wales. Ministry of Agriculture Fisheries and Food, London, UK.

Molenat, J., Durand, P., Gascuel-Odoux, C., Davy, P. and Gruau, G., 2002. Mechanisms of nitrate transfer from soil to stream in an agricultural watershed of French Brittany. Water Air Soil Pollut., 133, 161-183.

Nash, J.E. and Sutcliffe, J.V., 1970. River flow forecasting through conceptual models. Part 1 a discussion of principles. J. Hydrol., 10, 282-290.

Petry, J., Soulsby, C., Malcolm, I.A. and Youngson, A.F., 2002. Hydrological controls on nutrient concentrations and fluxes in agricultural catchments. Sci. Total Envir., 294, 95-110.

Robson, A., Beven, K. and Neal, C., 1992. Towards identifying sources of subsurface flow: a comparison of components identified by a physically-based runoff model and those determined by chemical mixing techniques. Hydrol. Process., 6, 199-214.

Ruiz, L., Abiven, S., Durand, P., Martin, C., Vertes, F. and Beaujouan, V., 2002a. Effect on nitrate concentration in stream water of agricultural practices in small catchments in Brittany: I. Annual nitrogen budgets. Hydrol. Earth Syst. Sci., 6, 497505 .

Ruiz, L., Abiven, S., Martin, C., Durand, P., Beaujouan, V. and Molenat, J., 2002b. Effect on nitrate concentration in stream water of agricultural practices in small catchments in Brittany: II. Temporal variations and mixing processes. Hydrol. Earth Syst. Sci., 6, 507-513.

Shaffer, M.J., Wylie, B.K., Follett, R.F. and Bartling, P.N.S., 1994. Using climate/weather data with the NLEAP model to manage soil nitrogen. Agr. Forest Meteorol., 69, 111-123.

Smith, R.A., Schwarz, G.E. and Alexander, R.B., 1997. Regional interpretation of water-quality monitoring data. Water Resour. Res., 33, 2781-2798.

Soulsby, C., Chen, M., Ferrier, R.C., Helliwell, R.C., Jenkins, A. and Harriman, R., 1998. Hydrogeochemistry of shallow groundwater in an upland Scottish catchment. Hydrol. Process, 12, 1111-1118.

Soulsby, C., Petry, J., Brewer, M.J., Dunn, S.M., Ott, B. and Malcolm, I.A., 2003. Identifying and assessing uncertainty in hydrological pathways: a novel approach to end member mixing analysis in a Scottish agricultural catchment. J. Hydrol., 274, 109-128.

Wade, A., Neal, C., Soulsby, C., Smart, R., Langan, S. and Cresser, M., 1999. Modelling stream water quality under varying hydrological conditions at different spatial scales. J. Hydrol., 217, 266-283.

Whitehead, P.G., Wilson, E.J. and Butterfield, D., 1998. A semidistributed Integrated Nitrogen model for multiple source assessment in Catchments (INCA): Part I - model structure and process equations., Sci. Total Envir., 210, 547-558.

Wiesner, C.J., 1970. Hydrometeorology. Chapman and Hall, London, UK. 232pp.

Yuan, M. and Duchon, C.E., 2001. Estimation of daily area-average rainfall in central Florida using arithmetic averaging and kriging, Phys. Geogr., 22, 42-58. 